\title{
APLIKASI PENYEWAAN ALAT BERAT PADA PT. TRI HARFI MANDIRI MENGGUNAKAN PEMPROGRAMAN VISUAL
}

\author{
Fakhriani Ekawati \\ Universitas Islam Kalimantan Muhammad Arsyad Al Banjari Banjarmasin \\ Email : fakhrianiekawati@gmail.com
}

\begin{abstract}
ABSTRAK
PT. Tri Harfi Mandiri merupakan salah satu perusahaan yang bergerak dalam bidang penyewaan alatalat berat, ada banyak jenis alat-alat berat yang disewakan disana seperti Loader, Dozer, Grabe, Eksavator, Motor Grader. Namun dalam proses aktifitas penyewaan alat berat ini masih terdapat beberapa kendala dalam melakukan penetapan biaya sewa dengan cepat, karena dalam penetapan biaya sewa belum terdapat tool yang baku, sehingga penetapan biaya sewa sangat dipengaruhi oleh subjektifitas pribadi, kondisi ini mengakibatkan tidak adanya kepastian harga sewa, juga proses penetapan akan memakan waktu. Seringkali perusahaan mengeluh karena dalam proses pengolahan data sering terjadi tumpang tindih nya data, sehingga jika ingin mengevaluasi dan menganalisa data pelanggan akan menjadi sulit. Aplikasi ini memberikan informasi seputar penyewaan, pengembalian, serta pemberian informasi kepada penyewa tentang jenis alat-alat berat yang tersedia. Program aplikasi ini juga menghasilkan tampilan berupa laporan seputar penyewaan alat-alat berat. Perancangan program aplikasi penyewaan alat-alat berat pada PT. Tri Harfi Mandiri ini menggunakan Visual Basic 6.0 sebagai bahasa pemprograman, dan Microsoft Access sebagai basis data. Dengan menggunakan aplikasi ini diharapkan dapat memudahkan perusahaan untuk mengevaluasi dan menganalisa data pelanggan bagi kemajuan PT. Tri Harfi Mandiri Banjarmasin.
\end{abstract}

\section{Keywords: Aplikasi Penyewaan, Database, Visual Basic, Micorosoft Access}

\section{PENDAHULUAN}

\subsection{Latar Belakang Masalah}

Bisnis alat berat di Indonesia sejak beberapa tahun terakhir ini kembali bergairah sejalan dengan makin bergairahnya pasar dalam negeri sebagai dampak dari makin meningkatnya permintaan akan alat-alat berat oleh sektor pertambangan, agroindustri, dan sektor konstruksi. Menurut perkiraan pemerintah, setiap tahunnya Indonesia membutuhkan sekitar 15.000 unit alat-alat berat dari berbagai jenis yang sebagian masih harus diimpor karena produsen lokal baru mampu memenuhi sekitar $65 \%$-nya saja.

PT. Tri Harfi Mandiri di Banjarmasin merupakan perusaahan yang bergerak di bidang bongkar muat, pengiriman agen dan layanan untuk semua kargo, terutama untuk pengiriman transportasi batubara. Untuk mencapai apa yang pelanggan butuhkan maka PT. Tri Harfi Mandiri memberikan beberapa layanan, salah satunya adalah penyewaan alat berat. Namun dalam proses aktifitas penyewaan alat berat ini masih terdapat kendala dalam melakukan penetapan biaya sewa dengan cepat, karena dalam penetapan biaya sewa belum terdapat tool yang baku, sehingga penetapan biaya sewa sangat dipengaruhi oleh subjektifitas pribadi, kondisi ini mengakibatkan tidak adanya kepastian harga sewa, juga proses penetapan akan memakan waktu. Seringkali perusahaan mengeluh karena dalam proses pengolahan data sering terjadi tertumpangnya data, sehingga jika ingin mengevaluasi dan menganalisa data pelanggan akan menjadi sulit.

\subsection{Rumusan Masalah}

Penelitian ini dibuat adalah bagaimana membuat aplikasi untuk membantu dalam perhitungan biaya penyewaan alat berat yang sesuai dengan standar yang telah ditentukan oleh perusahaan tersebut.

\subsection{Batasan Masalah}

Untuk menghindari pembahasan yang lebih luas maka ruang lingkup permasalahan dibatasi sebagai berikut : 
1. Penelitian ini dibatasi pada analisa biaya penyewaan alat berat khususnya untuk proses dalam kegiatan stevedoring, loading dan hauling pada PT. Tri Harfi Mandiri.

2. Aplikasi ini tidak menangani pembayaran secara online.

3. Tidak menanggulangi masalah yang berkaitan dengan sistem perpajakan dan bunga dari bank.

Tabel 1. Aturan Biaya Sewa Perjam Alat Berat

\section{PENELITIAN}

\subsection{Metode Pengumpulan Data}

Berikut merupakan data hasil dari wawancara, dokumentasi dan observasi di PT. Tri Harfi Mandiri, Jalan Sultan Adam No.3 RT.28 Banjarmasin, antara lain :

\begin{tabular}{|c|c|c|c|c|}
\hline Kode Alat Berat & $\underline{\text { Jenis }}$ & $\underline{\text { Merk }}$ & $\underline{\text { Status }}$ & $\underline{\text { Biaya }}$ \\
\hline DAB1002 & Traktor & CAT & Tersedia & Rp.2.750.000/hari \\
\hline DAB1001 & Loader & Komatsu & Tersedia & Rp.2.500.000/hari \\
\hline DAB1004 & Buldozer & Hyundai & Tersedia & Rp.3.250.000/hari \\
\hline DAB1005 & Eksavator & Kobelco & Tersedia & Rp.3.500.000/hari \\
\hline DAB1006 & Crane & Hitachi & Tersedia & Rp.5.000.000/hari \\
\hline DAB1007 & Loader & Hyundai & Tersedia & Rp.2.250.000/hari \\
\hline DAB1008 & Crane & CAT & Tersedia & Rp.5.150.000/hari \\
\hline DAB1009 & Loader & Hyundai & Tersedia & Rp.2.300.000/hari \\
\hline DAB1010 & Traktor & Komatsu & Tersedia & Rp.3.000.000/hari \\
\hline DAB1011 & Buldozer & CAT & Tersedia & Rp.3.250.000/hari \\
\hline
\end{tabular}

Sumber : PT. Tri Harfi Mandiri

Ketentuan:

a. Dengan minimal peminjaman 15 hari.

b. Denda akan di kenakan apabila pengembalian alat melewati batas yang telah di sepakati dalam kontrak.

c. Denda berupa biaya tambahan, apabila melewati batas 1 hari maka akan dikenakan biaya 1 hari sewa dan begitu pula seterusnya.

d. Tidak termasuk biaya pengiriman. Segala akomodasi dan transportasi (Trailer) dan pengawalan petugas di tanggung oleh pihak renter atau penyewa.

\subsection{Analisis dan Perancangan}

Sistem informasi dibangun dengan menggunakan pendekatan terstruktur.
Diagram konteks (Context Diagram) dan diagram aliran data (Data Flow Diagram, DFD) digunakan sebagai alat bantu perancangan sistem. Sedangkan diagram relasi entitas (Entity Relationalship Diagram, ERD) Pada sistem ini terdapat dua entitas eksternal, yaitu administrator sistem dan manajer. Administrator sebagai penanggung jawab sistem sekaligus memasukkan data-data info yang akan di input ke dalam sistem, sedangkan manajer merupakan entitas yang akan menerima informasi dari sistem. Gambar di bawah menunjukkan diagram konteks untuk sistem ini. 


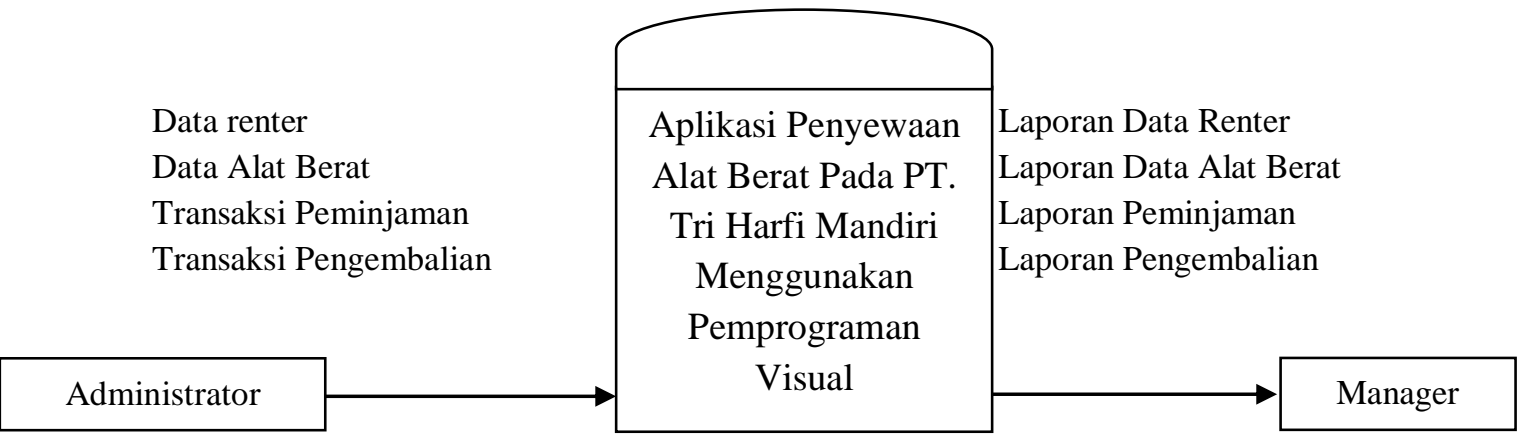

Gambar 1. Diagram Konteks

\subsection{Data flow diagram (DFD)}

DFD dibawah ini menunjukan rangkaian alur sistem aplikasi secara umum, yaitu :

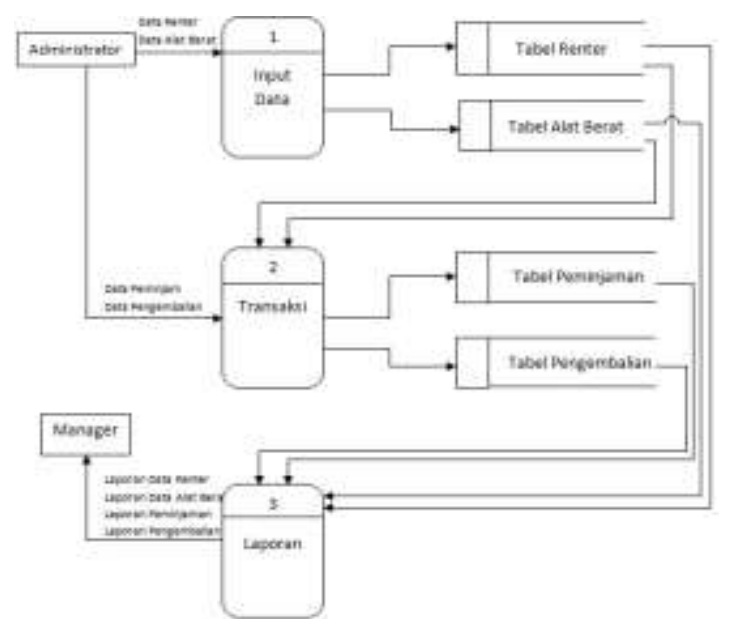

Gambar 2. Data Flow Diagram Level Nol

(0)

\subsection{Data flow diagram (DFD) Level 1}

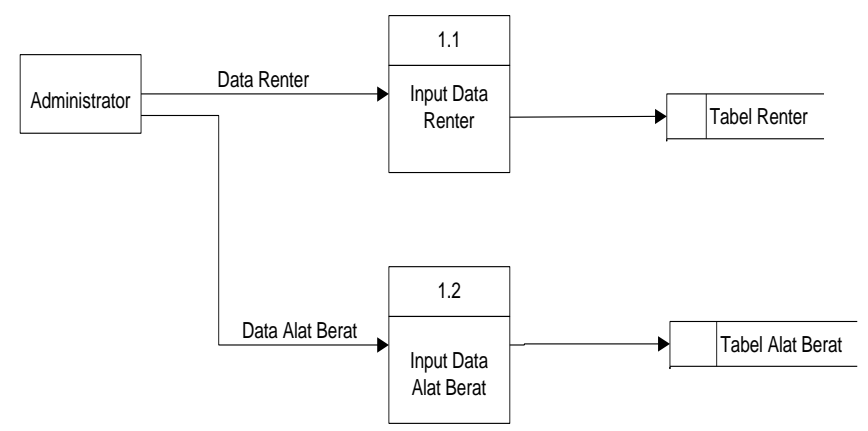

Gambar 3. DFD level 1 proses input data

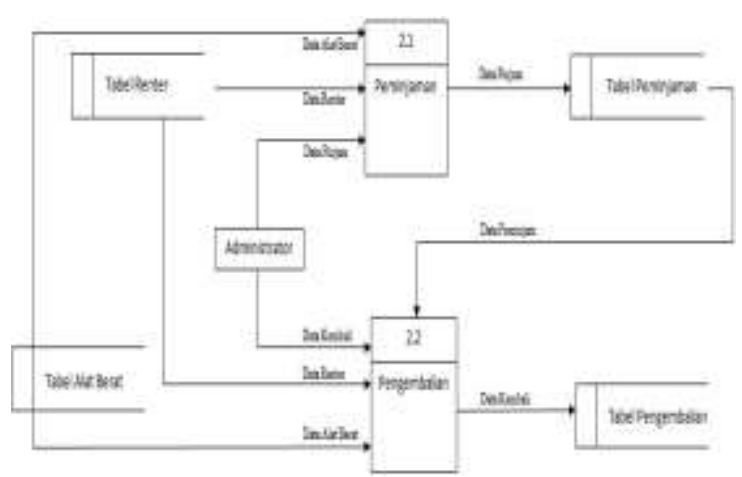

Gambar 4. DFD level 1 untuk proses transaksi

\section{HASIL DAN PEMBAHASAN}

\subsection{Tampilan Menu Login}

Tampilan login untuk masuk ke menu utama program Penyewaan Alat Berat pada PT. Tri Harfi Mandiri. Inputan Username dan Password dengan benar setelah itu tekan button Login maka menu program bisa digunakan.

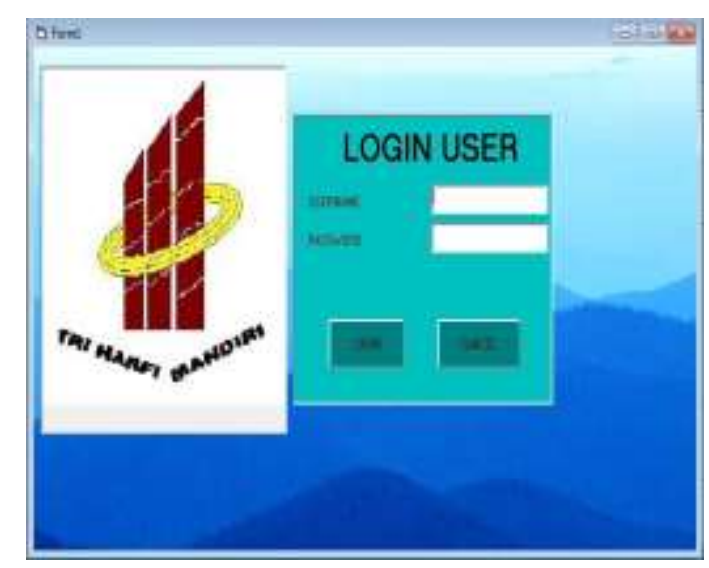

Gambar 5.Tampilan Login

Tampilan menu program Penyewaan Alat Berat pada PT. Tri Harfi Mandiri saat login. 


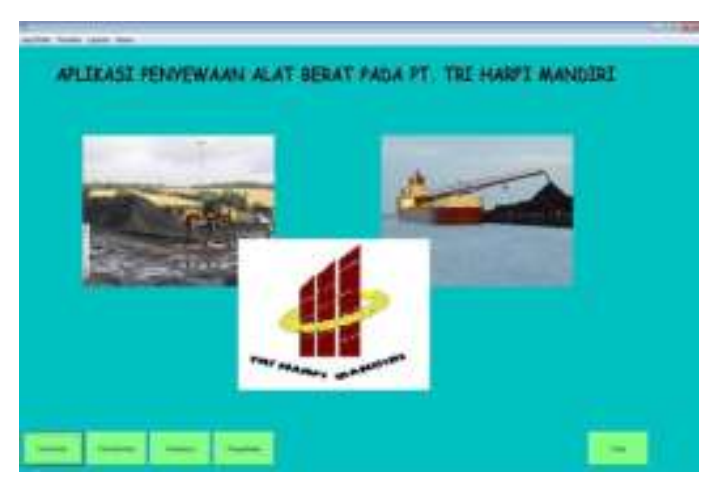

Gambar 6. Tampilan Menu Utama

Apabila dalam penginputan Username dan Password salah maka akan keluar peringatan seperti gambar berikut :

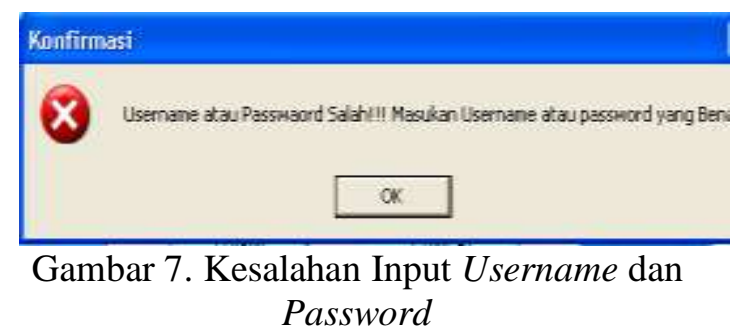

Ketika di tekan tombol OK, menu login akan muncul kembali, dan pengguna bias menginputkan Username dan Password kembali hingga benar.

Di menu utama ini ada terdapat beberapa komponen yaitu :

1. Input Data

Di menu ini terdapat beberapa komponen seperti Data Renter dan Data Alat Berat.

2. Transaksi

Di menu ini terdapat beberapa komponen seperti Peminjaman dan Pengembalian.

3. Laporan

Di menu ini terdapat beberapa komponen seperti Cetak Data, Cetak Data Alat Berat, Cetak Transaksi Peminjaman, Cetak Transaksi Pengembalian.

4. Keluar

Di menu ini digunakan untuk mengakhiri semua program yang sedang berjalan

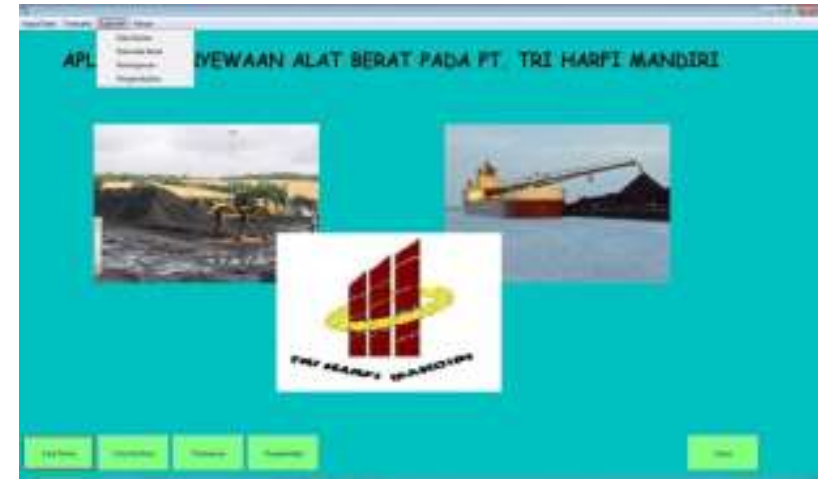

Gambar 8. Tampilan Komponen dalam Menu Utama

\subsection{Tampilan Menu Input}

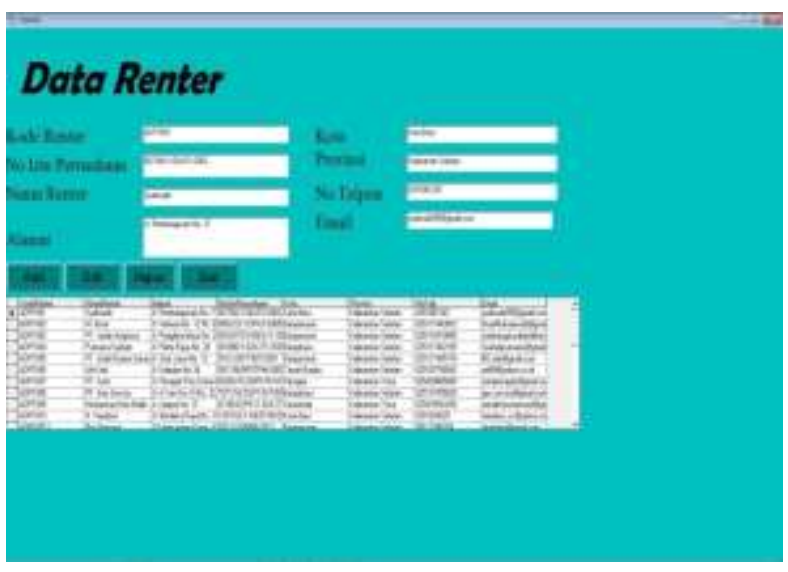

Gambar 9. Tampilan Form Input Data Renter

Data Renter di pilih pada menu Input Data, pada form ini terdapat tombol save, batal, add, edit, hapus dan exit. Ketika data renter di inputkan maka tombol simpan dan batal akan aktif, jika data belum lengkap maka akan keluar peringatan seperti yang pada gambar 10, peringatan ini akan muncul apabila ID Renter sudah ada atau data belum lengkap di isi.:

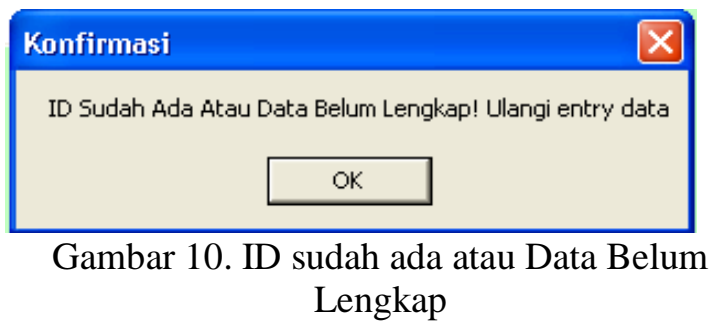




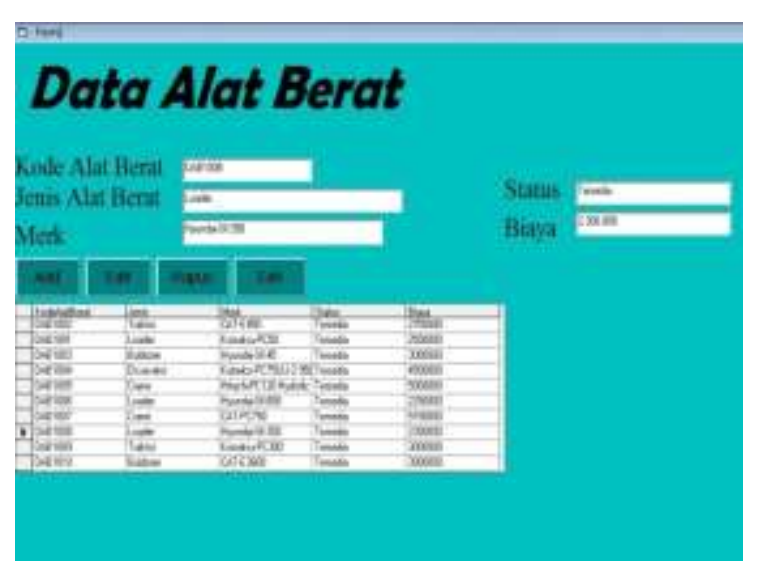

Gambar 11. Tampilan Input Data Alat Berat

Tampilan gambar di atas ini akan tampil ketika Data Alat Berat di pilih pada menu Input Data, pada form ini terdapat tombol cetak, add, edit, hapus dan exit. Ketika data alat berat di inputkan maka tombol simpan dan batal akan aktif. Ketika data alat berat di input dan di simpan secara otomatis data tersebut tampil pada datagrid dan tersimpan dalam database yang digunakan

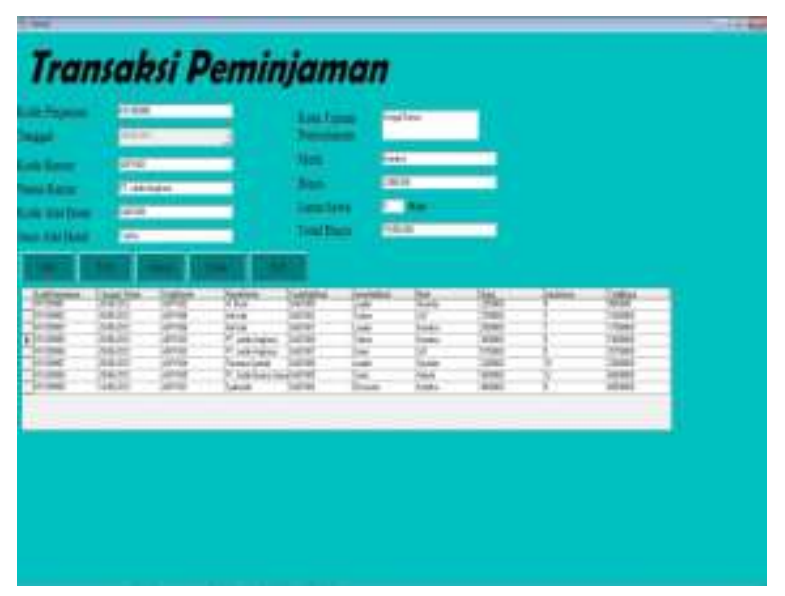

Gambar 12.Tampilan Input Transaksi Peminjaman

Tombol Peminjaman di pilih pada menu Transaksi, pada form ini terdapat tombol cetak, add, edit, hapus dan exit. Ketika data transaksi peminjaman di inputkan maka tombol simpan dan batal akan aktif. Ketika data transaksi peminjaman di input dan di simpan secara otomatis data tersebut tampil pada datagrid dan tersimpan dalam database yang digunakan.

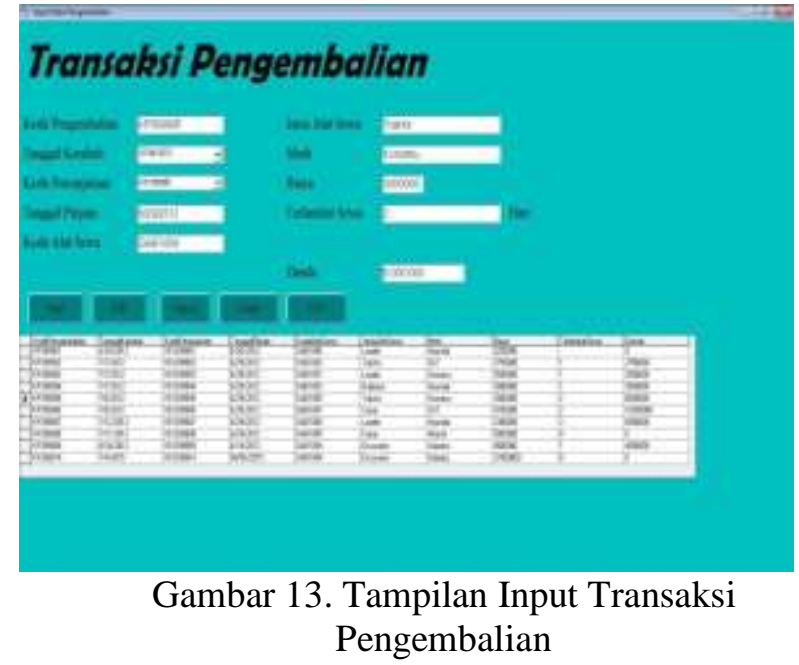

Tombol Pengembalian di pilih pada menu Transaksi, pada form ini terdapat tombol cetak, add, edit, hapus dan exit. Ketika data transaksi pengembalian di inputkan maka tombol simpan dan batal akan aktif. Ketika data transaksi pengembalian di input dan di simpan secara otomatis data tersebut tampil pada datagrid dan tersimpan dalam database yang digunakan.

\subsection{Tampilan Menu Output}

Tampilan ini menampilkan hasil dari pencetakan data yaitu Cetak Data, Cetak Data Alat Berat, Cetak Transaksi Peminjaman, Cetak Transaksi Pengembalian. Pada pencetakan Data Renter memiliki kategori berdasarkan Per ID dan Cetak Semua Data seperti terlihat pada gambar 13 :

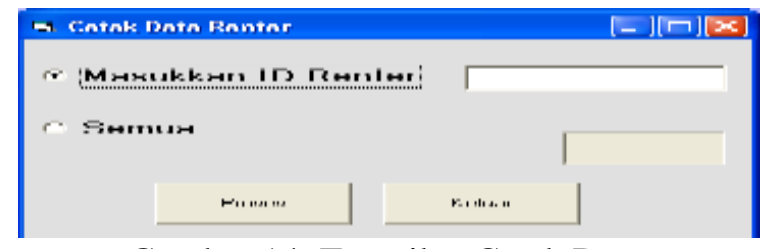

Gambar 14. Tampilan Cetak Data Renter

Jika pengguna memilih kategori berdasarkan cetak semua data maka akan tampil laporan seperti gambar di bawah ini : 


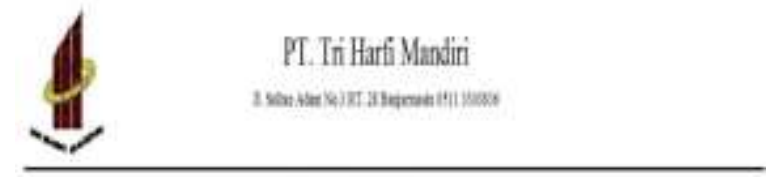

\begin{tabular}{|c|c|c|c|c|c|c|c|}
\hline \multicolumn{8}{|c|}{ DATA RENTER } \\
\hline bester & star & ane & Nutreatua & ia & $\max$ & $\infty$ & tout \\
\hline$a m$ & $=$ & 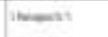 & pentian & ints & anes & eny & -ater: \\
\hline one & $n$ & nmaiai & mas & - & מרen & fenas & 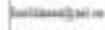 \\
\hline$m$ & $\pi=-$ & inmenses & nernisan & $m$ & inme- & ext & thenten \\
\hline ow & theries & $m-1$ & masen & r & hase & $n=w$ & - \\
\hline an & Ninelont & 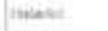 & mares & - & 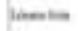 & exen & misters \\
\hline anis & ist & thets & antantar & wats & 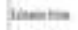 & erm & tent \\
\hline ar & n= & $n+m \rightarrow \infty$ & masis & - & thesels & oune & - \\
\hline कom & Hewm & somenes & parses & - & vemer & ene & $+\infty$ \\
\hline gin & 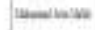 & 1100 & fanang & $m$ & lanest & ous= & 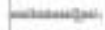 \\
\hline leme & tith & 11-mon & реынау & ist) & 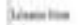 & evee & 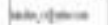 \\
\hline ene & bitum & 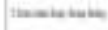 & Suani & 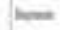 & 1eser & enses: & $m$ \\
\hline an: & name & $1=0$ & minas & 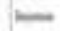 & 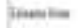 & man & $\infty$ \\
\hline
\end{tabular}

Gambar 15. Tampilan Output Cetak Data Renter

Pada pencetakan Data Alat Berat memiliki kategori berdasarkan Per ID dan Cetak Semua seperti terlihat pada gambar berikut :

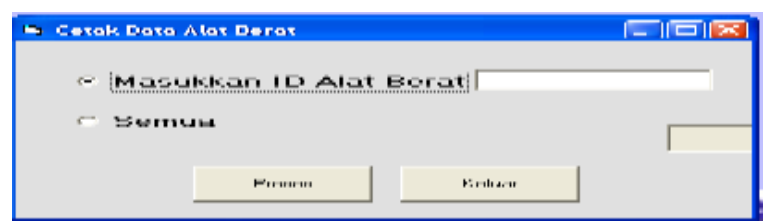

Gambar 16. Tampilan Cetak Data Alat Berat

Form ini dirancang untuk menampilkan output Data Alat Berat Pada PT. Tri Harfi Mandiri. Secara Lengkap tampilan form output tersebut dapat dilihat pada gambar berikut :

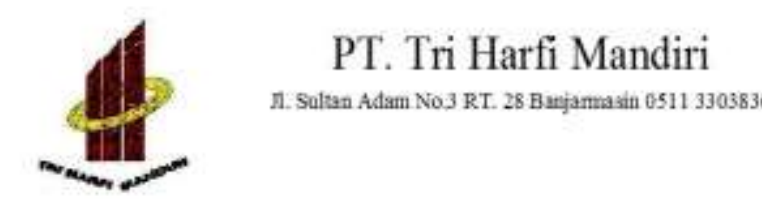

Pada pencetakan Transaksi Peminjaman memiliki kategori berdasarkan Per ID dan Cetak Semua Data.

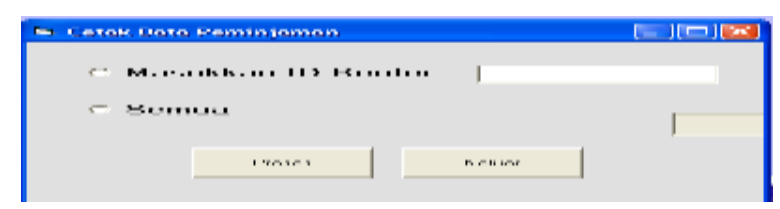

Gambar 18. Tampilan Cetak Data Transaksi Peminjaman

Jika pengguna memilih kategori berdasarkan cetak semua data maka akan tampil laporan seperti gambar di bawah ini :

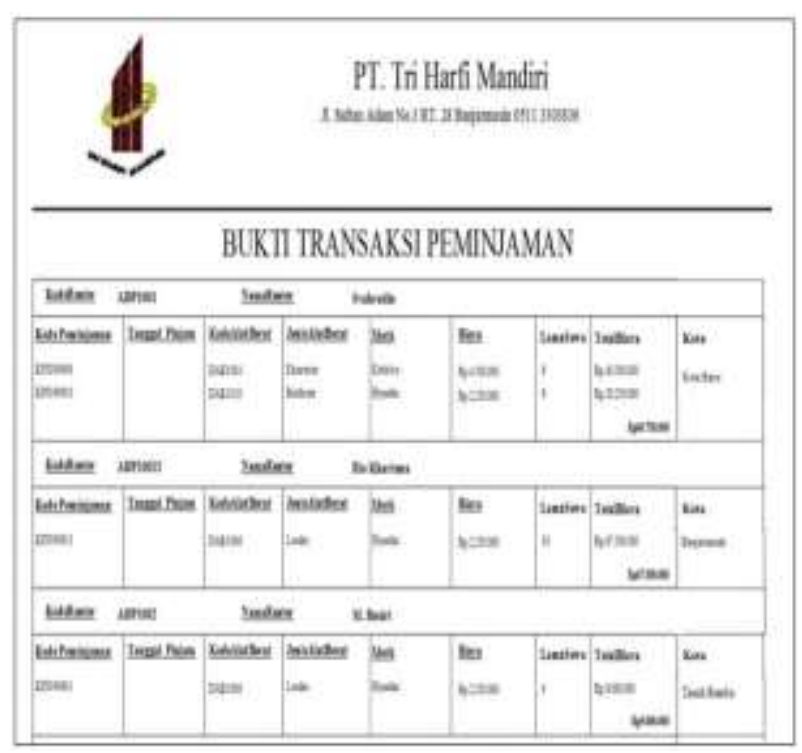

Gambar 19. Tampilan Output Cetak Data Transaksi Peminjaman

Pada pencetakan Transaski Pengembalian memiliki kategori berdasarkan bulan dan tahun seperti terlihat pada gambar berikut :

\begin{tabular}{|c|c|c|c|c|}
\hline KoletleRern & Iali & Mert & $\operatorname{sen}$ & Bime \\
\hline Dealo02 & Intart & CASEASI & Tentst & $B \neq 2 \pi v i x$ \\
\hline Dasust & Labat & Kenatu.kest & Tanuta & $172500 \times x$ \\
\hline Dasions & Anterer & Mysatai ix et & Thest & Kq toee ixe \\
\hline DAsionu & Elownorer & 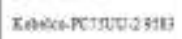 & Terosta & Rousenoto \\
\hline Dastors & Cats & Hhalla-PC120 Hyini: & Ienebs & Bestocos 20 \\
\hline Diation & Initur & Hyate-IKe?0 & Innt & Pq230xx \\
\hline Dation? & Canes & chracisa & Intumb & Ipsisuave \\
\hline Dasioet & Leabir & Hyantaisxije & Terosts & $x_{F}=21000 x$ \\
\hline Dusioge & Trath & Eanan-PCase & Trivat & $v_{0}+60002 x$ \\
\hline Deselore & Butear & Chraies & Teriesta & Das 3000100 \\
\hline
\end{tabular}

Gambar 17. Tampilan Output Alat Berat

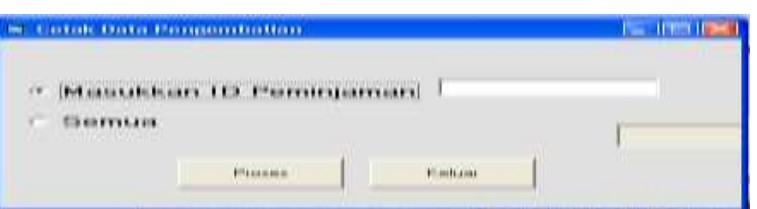

Gambar 20. Cetak Data Transaksi

Pengembalian

Form ini dirancang untuk menampilkan output Data Transaksi Pengembalian Pada PT. Tri Harfi Mandiri. Secara Lengkap tampilan form output tersebut dapat dilihat pada gambar berikut : 

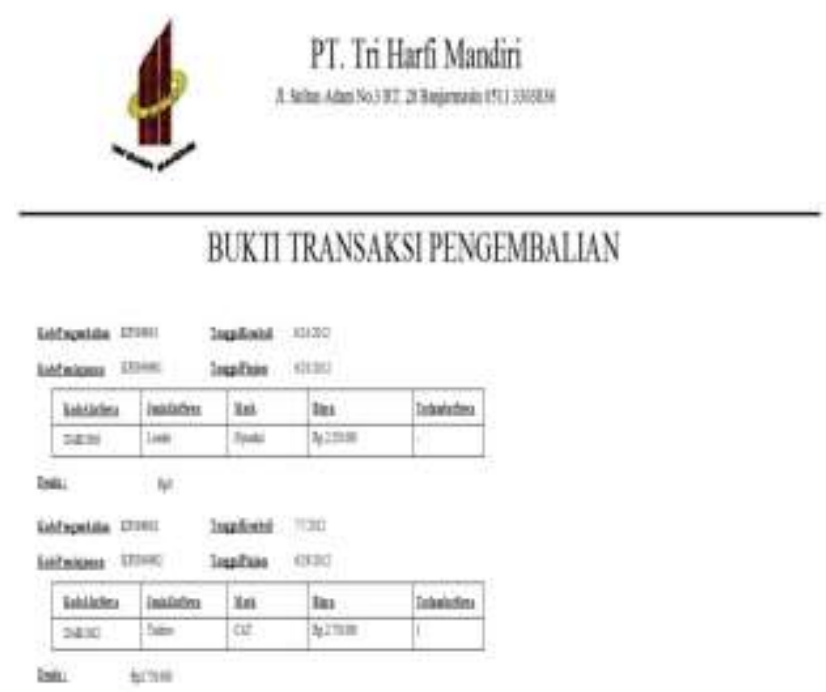

Gambar 21. Tampilan Output Cetak Data Transaksi Pengembalian

Tampilan ini akan tampil ketika menu keluar di pilih, dimana menu keluar ada pada deretan paling akhir. Tampilan menu keluar ini menghasilkan dua pertanyaan, apabila ingin keluar dari program maka pilih tombol Yes tapi apabila ingin membatalkannya pilih tombol $N o$ terlihat pada gambar berikut :

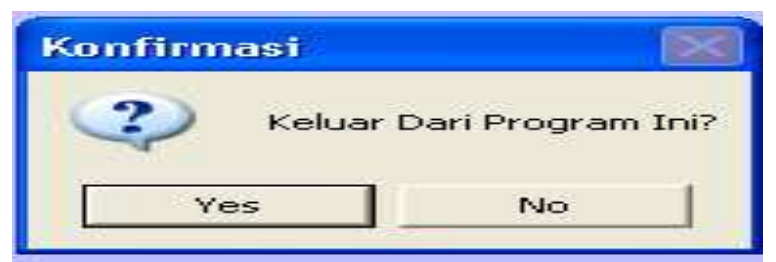

Gambar 22. Tampilan Menu Keluar

\section{PENUTUP}

Setelah dilakukan penelitian dan pembahasan tentang Penyewaan alat berat pada PT. Tri Harfi Mandiri, maka ditarik kesimpulan yaitu :

1. Program Penyewaan Alat Berat pada PT. Tri Harfi Mandiri ini dapat digunakan sebagai program bantu yang sebelumnya masih menggunakan Microsoft Excel dan Microsoft Word.

2. Program Penyewaan Alat Berat pada PT. Tri Harfi Mandiri ini dapat digunakan sebagai acuan karyawan dalam menginputkan data-data
Penyewa/Renter serta data-data Alat Berat, hal ini tentunya mempermudah kerja dan mempersingkat waktu dalam melakukan pekerjaan tersebut.

\section{REFERENSI}

Davis B,Gordon, 1990, "Sistem Informasi

Manajemen", Jakarta : PPM

Jogiyanto H.M, 2001, “Analisis dan Desain”, Yogyakarta : Andi Offset, Cetakan Kedua.

Nugroho, Bunafit, 2005, "Database Relasional", Andi Offset, Yogyakarta.

Prasetyo, Dwi, 2007, "101 Tip \& Trik Buku Kedua”, Yogyakarta : Elexmedia Komputindo.

Sihombing, Mustika Anggriani,2010, Pelaksanaan Perdagangan Alat-Alat Berat Dan Mekanisme Pembayaran Pada PT United Tractors, Tbk, http://repository.usu.ac.id/handle/123456789/17 459, diakses tanggal 01 Agustus 2018 